\title{
MANIFESTO DAS FILOSOFIAS OUTRAS
}

O outro é aquilo que eu não sou. Ou, o outro é o não-eu. E eu sou, eu existo; de mim emana o mundo. Assim, a mulher é o outro do homem; o negro o outro do branco; o homo o outro do hetero; o trans o outro do cis. O outro é o monstro, o que sobra, o que é controlado, moldado e transformado para servir o mesmo, o eu. Nesta revista não fazemos uma apologia do outro; não é um elogio do outro; não é uma ode a outridade, como uma identidade pela não-identidade. Não. Essa revista começa com esse breve manifesto: são nossos interesses e intenções com um projeto político - no sentido mais forte do termo - por e com uma Filosofia Outra.

É outra porque viramos o jogo. O eu é o não-outro; o eu é aquilo que não é outro, e não sendo outro é o mesmo. É do outro que o mundo emana, e é pelo outro que existe a vida. Sem outro não há eu, não há sujeito, não há mundo; não há filosofia. E essa filosofia outra, é outra porque luta pelo diverso, pelo múltiplo, pelo não uno e não unificante; ela é pelo direito de ser diferente: é a arma com a qual lutamos por outros modos de vida.

O ocidente é cristão. Com isso não dizemos nada de novo - nem queremos -, mas tampouco abordamos o problema. O ocidente dissemina seus valores e sua razão; seu modo de vida e pensamento se impôs ao mundo, e a globalização dos seus valores é a destruição do mundo - do mundo como multiplicidade. Mas esses valores não são valores cristãos; sua racionalidade não é a razão de Deus. O ocidente é o capitalismo; seu projeto civilizatório é a destruição do diferente, do outro. O outro é irracional, é irredutível, é incontrolável. O outro precisa ser destruído.

Lukács nos canta a bola: o capitalismo - que a alguns autores apetece chamar de modernidade - é o projeto da razão consumado na vida. É a vida moldada pela razão em formas abstratas - a saber, pela forma da forma, a mercadoria enquanto forma de produção. A vida, irracional e múltipla em sua particularidade, em sua singularidade se mostra apreensível pela razão; porque na concretude e efetividade de sua singularidade, a vida, contrária em seus momentos, se mostra una e completa na totalidade dos mesmos. 
Mas a razão destrói a totalidade. Ela destrói a totalidade pois desorganifica a vida em seus momentos particulares. Eles se tornam previsíveis, passíveis de cálculo e racionalidade. Os momentos da vida se tornam abstratos, artificialmente separados, roboticamente unificados. A totalidade da vida se torna irracional. Irracional porque incompreensível; morta, porque seus momentos particulares não possuem qualquer unidade possível. A totalidade se torna contraditória.

Na razão capitalista o outro é o momento irredutível e irracional, que não se conforma e não se adequa. É um singular em si e por si; e isso é inadmissível. Ele precisa ser o mesmo, ele precisa ser calculável; se não for destruído, a razão entra em colapso, pois ela precisa ser universal. A forma mercantil precisa ser a forma universal de todo ser social; não o sendo, ela entra em colapso. O outro é perigoso. O outro é a forma que estilhaça o mesmo. Por isso o outro é mais que r-existência, é a luta constante por outros valores: outra epistemologia, outra estética, outra ética, outra política... Uma luta por uma vida outra.

Uma luta por outra vida, por outros modos de vida, é uma luta pelo novo; ou melhor, por um futuro aberto, um futuro diferente. Um futuro como não a mera projeção do presente, do mesmo. Um futuro onde a história seja mais que a repetição do passado, consolidado em formas perenes e eternas. $\mathrm{O}$ outro é também a ruptura, o diferente: aquilo que não é agora, nem poderia ser. Não é, nem poderia ser, pois como novo, pois como ruptura, é aquilo que nem podemos conceber. Ninguém faz o novo, o novo acontece; como acontecimento, é uma ruptura, o inédito e indescritível, que rompe com o presente, para o reorganizar.

Assim também, e por motivos semelhantes, ninguém é o outro. O outro é. Assim tão simplesmente. O mesmo é não-ser; ele não é porque o outro é. O mesmo é a não-vida; porque vida é mudança e criação, vida é novo. O mesmo não é novo, porque é o mesmo. Tudo aquilo que o outro é, o mesmo não é; mas por ser, o outro é ameaça, é incontrolável, é puro movimento e devir. O outro é a morte do mesmo; porque o mesmo é a morte; o outro, a vida. Que sobra é matar o outro, destruir o outro, suprimir a diferença. Daí nada pode surgir.

O futuro deve ser o mesmo; deve ser o que sempre foi. Não há mais futuro; o tempo parou. Muda para não mudar. Tudo muda, para permanecer o mesmo... E o mesmo permanece, pois o futuro agora é o presente projetado à frente, como uma sombra de árvores mortas. As folhas adubam o chão, mas na sombra vida nenhuma nasce. Pois não há onde nascer. As folhas que adubam o solo são ilusões - há muito já morreram; não há luz para alimentar a vida nova germinada. Todo gérmen, toda semente de um mundo novo morre à sombra do presente projetado. O presente se apresenta como uma forma eterna e etérea, que vai sufocar tudo o que se contrapõe a si. O outro perece. Padece a cada dia pela negação daquilo que ele é: vida.

Antes do messias, antes da redenção virá o anticristo, como presságio do mal e atraso do tempo. O anticristo para o tempo; o messias virá 
trazer o novo. Estrelas brilham no céu. São luzes, nos guiam na noite que nos assola. Um espectro de luz ronda a filosofia. Há de iluminar e deixar viver a multiplicidade. Assim se apresenta nossa revista, como um manifesto contra a filosofia da mesmecidade, por uma filosofia que possa ser outra.

\section{Coletivo do NESEF}

